\title{
Microfracture of the Knee: Are The Results Achieved In Clinical Practice Statistically Comparable to Those Presented in Controlled Studies?
}

\author{
Lukas Leopold Negrin and Vilmos Vécsei \\ Department of Trauma Surgery, Medical University of Vienna, Austria
}

\begin{abstract}
Purpose: To proof the hypothesis that the results achieved by microfracture of the knee in clinical practice are not statistically comparable to those presented in controlled studies. Methods: Our literature search focused on patients with full-thickness cartilage defects of the knee who were treated with microfracture without implantation of a scaffold or injection of substitutes and whose functional capacity was assessed by clinical scores. Whereas these patients formed group A, group B consisted of 26 patients who had been treated at our Level I trauma center. The decision if microfracture was appropriate was made during an arthroscopy of the knee that was scheduled for the repair of meniscal and/or ligamental deficiencies. Due to missing preselection no exclusion criteria were defined. We compared the two groups by performing a correlation analysis. Results: Four randomized controlled trials and one prospective cohort study were detected which provided 187 patients for group A. Surprisingly, a very high correlation (Pearson coefficient $r=0.924, p=0.008$ ) was calculated between the score values, indicating similar postoperative outcome in both groups. Conclusions: Controlled studies may reflect general population results and therefore provide estimates of treatment effects which are applicable in usual clinical practice.
\end{abstract}

Key words: Knee joint, microfracture, correlation study, clinical scores, outcome.

\section{Introduction}

In 1980, microfracture, a single-stage arthroscopic technique, was developed by Steadman [1]. After careful removal of the calcified cartilage layer and after debridement of the lesion until stable cartilage margins are reached, multiple holes are made in the exposed bone with an awl. The resulting tiny fractures ("microfractures") enable bone marrow cells to migrate into the cartilage defect and to create a "super clot" that eventually matures into firm repair tissue. Initially, the efficiency of microfracture was demonstrated for athletes $[1,2]$ and for traumatic lesions [3]. Due to the good results that had been achieved, the indication for this technique was expanded to degenerative defects $[4,5]$ as well as to

Corresponding author: Lukas Leopold Negrin, MD, MSc, research fields: cartilage, acetabulum, polytrauma. E-mail: lukas.negrin@meduniwien.ac.at. osteonecrosis [6]. Microfracture provides at least effective short-term improvement of knee function [7]. For this reason and due to its minimally invasive nature, technical ease, limited surgical morbidity, low costs and because it does not prevent the application of other cartilage repair procedures that may be needed in the future, microfracture has gained popularity over the past two decades [8-10]. It is now a common first-line treatment for patients with cartilage defects of the knee [11,12].

Undoubtedly, routinely seen patients who have to be treated surgically often do not correspond with the accurately selected homogenous patient population of a randomized controlled trial. Moreover, the symptoms of a full-thickness cartilage lesion can be superimposed by those of other pathologies like meniscal tears or a rupture of the anterior cruciate ligament. In most cases, the exact extent of the cartilage defect is diagnosed in the operating room 

Those Presented in Controlled Studies?

during the arthroscopy for the first time and the decision to perform microfracture has to be made spontaneously. Therefore, the goal of our study was to evaluate if the results achieved by microfracture used in clinical practice are statistically comparable to those presented in controlled studies, assuming that they will differ widely.

\section{Method}

\subsection{Literature Search}

We searched the electronic databases MEDLINE, EMBASE, CINAHL, and the Cochrane Central Register of Controlled Trials for controlled clinical trials or controlled prospective observational studies. Our literature search was completed on September 1, 2011. As "microfracture" is the generally accepted notation for this technique, we decided to use it as our search term. No language restrictions were applied. We focused on patients who were treated with microfracture without implantation of a scaffold or injection of substitutes and whose functional capacity was assessed by clinical scores. Moreover, our eligibility criteria included full-thickness cartilage defects which were located on the medial or lateral femoral condyle, the trochlea or the patella, caused by acute or repetitive trauma, osteonecrosis or osteochondritis dissecans. The minimum follow-up period was determined to be one year. Two reviewers independently assessed studies for inclusion and evaluated their internal validity. Studies with a high risk of bias were excluded from further analyses and discrepancies were resolved by consensus. All relevant controlled studies detected by our literature search provided the patients summarized as group A. Undoubtedly, the follow-up period plays an important role in outcome evaluation. On the one hand, maximum improvement achieved by microfracture was evaluated during the first two postoperative years $[1,3,13-16]$, probably as a result of the quantitative and qualitative repair tissue maturation $[3,17,18]$; on the other hand initial functional improvement started to deteriorate from 18 to 24 months postoperatively [19-24]. Therefore, the extracted score values of group A should refer to follow-up periods that were comparable to those of our patients. Moreover, an overall evaluation was not possible because score values of one particular patient can vary considerably depending on the chosen system [25-29]. Therefore, we only combined values to an average which referred to the same clinical score; it was determined to represent the mean score value of group A.

\subsection{Patients}

Group B was formed by 26 patients (19 male, seven female) who had been treated with the microfracture technique at our Level I trauma center. During a follow-up examination these patients agreed to subjectively evaluate their knee by a self-explanatory questionnaire which included eight numerical knee scores as well as the Tegner Score. Only probands were admitted if their surgery had been performed more than twelve months before starting the evaluation. For all patients - all of them were treated by two attending surgeons - an arthroscopy was scheduled for the treatment of meniscal lesions and/or ligament reconstruction. Nevertheless, all patients had been informed about possible additional procedures and associated risks. Therefore, in case of diagnosing a cartilage defect, the decision for microfracture could be taken intraoperatively, if it was considered appropriate by the surgeon. Due to missing preselection no exclusion criteria were defined, resulting in a heterogeneous patient population with an average age of 39.7 (15-63) years, an average BMI of $27(20-38) \mathrm{kg} / \mathrm{m}^{2}$ and an average follow-up period of 35 (12-67) months. The cartilage lesions classified as grade 3 or 4 according to Outerbridge had an average size of $216(39-589) \mathrm{mm}^{2} .24$ patients had focal defects. Of the 28 lesions, five were located on the lateral and 20 on the medial femurcondyle, one was located on the lateral and on the medial tibial plateau each and one was retropatellar. All of the 26 

Those Presented in Controlled Studies?

investigated patients had additional injuries, i.e., 23 meniscal tears, six anterior cruciate ligament ruptures, five plicae, one torn medial collateral ligament, one case of loose bodies, one non-treated retropatellar cartilage defect and one combined fracture of the patella and the tibial plateau. Eight knees have had at least one prior surgery. Nine patients with a Tegner Score of 5 or more were classified as athletes. The demographic data of group B are presented in Table 1.

Table 1 Demographic data of group B.

\begin{tabular}{|c|c|c|c|c|c|c|c|c|c|}
\hline Number & Sex & Age & BMI & Knee & Localisation & \begin{tabular}{|c|} 
Size \\
$\left(\mathrm{mm}^{2}\right)$
\end{tabular} & \begin{tabular}{|l|l}
$\begin{array}{l}\text { Previous } \\
\text { surgery }\end{array}$ \\
\end{tabular} & Associated surgery & \begin{tabular}{|c|c|}
$\begin{array}{c}\text { Follow-up } \\
\text { (months) }\end{array}$ \\
\end{tabular} \\
\hline 1 & $\mathrm{~m}$ & 19 & 22,5 & left & LFC & 314 & no & Osteochondritis dissecans, mediopatellar plica & 64 \\
\hline 2 & $\mathrm{~m}$ & 38 & 30,6 & right & MFC & 79 & no & MM, ACL, patella and tibial condylar fracture & 29 \\
\hline 3 & $\mathrm{~m}$ & 63 & 38,3 & right & MFC & 471 & no & MM & 22 \\
\hline 4 & $\mathrm{f}$ & 32 & 28,3 & left & MFC & 118 & yes & LM & 12 \\
\hline 5 & $\mathrm{~m}$ & 45 & 32,8 & right & MFC & 118 & no & MM, LM, ACL & 19 \\
\hline 6 & $\mathrm{f}$ & 30 & 23,5 & right & LFC & 39 & no & MCL & 23 \\
\hline 7 & $\mathrm{~m}$ & 31 & 24,0 & right & MFC & 177 & no & MM & 24 \\
\hline 8 & $\mathrm{f}$ & 48 & 28,5 & right & MFC+LTP & 141 & yes & MM & 64 \\
\hline 9 & $\mathrm{~m}$ & 61 & 30,2 & right & MFC & 314 & yes & MM & 28 \\
\hline 10 & $\mathrm{~m}$ & 18 & 25,2 & right & MFC & 79 & no & MM & 41 \\
\hline 11 & $\mathrm{f}$ & 30 & 33,1 & right & MFC & 157 & yes & MM, LM, 2 loose bodies & 63 \\
\hline 12 & $\mathrm{~m}$ & 52 & 28,6 & left & MFC & 60 & no & MM, LM & 12 \\
\hline 13 & $\mathrm{~m}$ & 53 & 28,6 & right & MFC & 118 & no & MM, LM, infrapatellar plica & 58 \\
\hline 14 & $\mathrm{~m}$ & 44 & 27,2 & left & MFC & 589 & yes & MM, LM & 19 \\
\hline 15 & f & 48 & 20,2 & left & MFC & 118 & no & $\mathrm{MM}, \mathrm{ACL}$ & 21 \\
\hline 16 & $\mathrm{f}$ & 49 & 28,3 & right & MFC & 314 & no & LM, MM, patellar cartilage lesion & 17 \\
\hline 17 & $\mathrm{~m}$ & 48 & 25,3 & right & MFC & 393 & no & Infrapatellar plica & 42 \\
\hline 18 & $\mathrm{~m}$ & 40 & 27,1 & right & MFC & 118 & no & MM, infra- et mediopatellar plica & 17 \\
\hline 19 & f & 36 & 22,7 & left & LFC & 157 & yes & LM & 23 \\
\hline 20 & $\mathrm{~m}$ & 60 & 29,4 & left & MFC & 118 & no & MM, arthrosis grade 2 & 53 \\
\hline 21 & $\mathrm{~m}$ & 42 & 24,6 & left & MFC & 236 & no & MM, & 45 \\
\hline 22 & $\mathrm{~m}$ & 17 & 24,0 & left & LFC & 118 & yes & MM, ACL & 35 \\
\hline 23 & $\mathrm{~m}$ & 19 & 24,3 & right & MFC & 236 & no & LM, MM, ACL & 19 \\
\hline 24 & $\mathrm{~m}$ & 15 & 24,5 & right & LFC & 393 & no & LM & 49 \\
\hline 25 & $\mathrm{~m}$ & 40 & 21,6 & left & PAT & 177 & no & MM & 36 \\
\hline 26 & $\mathrm{~m}$ & 55 & 33,0 & right & $\mathrm{MFC}+\mathrm{MTP}$ & 471 & yes & $\begin{array}{l}\text { MM, LM, varus arthrosis grade 4, ligamentous } \\
\text { laxity }\end{array}$ & 67 \\
\hline
\end{tabular}

Note: $\mathrm{m}=$ male, $\mathrm{f}=$ female, $\mathrm{LFC}=$ lateral femoral condyle, MFC $=$ medial femoral condyle, $\mathrm{LTP}=$ lateral tibial plateau, $\mathrm{MTP}=$ medial tibial plateau, $\mathrm{PAT}=$ patella, $\mathrm{LM}=$ lateral meniscal rupture, $\mathrm{MM}=$ medial meniscal rupture, $\mathrm{ACL}=$ anterior cruciate ligament rupture, $\mathrm{MCL}=$ medial collateral ligament rupture).

Of all our patients, surgery and rehabilitation protocol were performed as described by Steadman [30]. His therapeutic regimen generally includes the use of a continuous passive motion machine (its impact on the outcome could not be detected [31]) starting in the recovery room. For lesions on the femoral condyle Steadman insists on crutch-assisted touchdown weight bearing for six to eight weeks, only rarely prescribing a brace, whereas weight bearing as tolerated is allowed for all patients with patellofemoral lesions, but they have to use a brace for 
at least eight weeks to prevent excessive sheer force on the maturing marrow clot.

\subsection{Statistical Analyses}

For comparison of the results of group $\mathrm{A}$ and $\mathrm{B}$ in their entirety and not score-by-score we allocated the score values of group A to the relevant score values of group B. In order to identify the degree of linear relationship between the two variables we performed a correlation analysis by calculating the Pearson coefficient. A p-value of 0.01 was assigned as the two-tailed significance level.

\section{Results}

Our literature search yielded 1,030 citations (MEDLINE: 391, EMBASE: 514, CINAHL: 105 and Cochrane Register: 20). Four randomized controlled trials [32-36] and one cohort study [37], the allocation of patients was determined by health and insurance policy) met our eligibility criteria; these papers are presented in Table 2. Accordingly, group A consists of 187 surgically treated patients aged between 15 and 60 years (mean 32.4 years) with chondral defects from $1 \mathrm{~cm}^{2}$ to $10 \mathrm{~cm}^{2}$ of size (mean $>244 \mathrm{~cm}^{2}$ ), evaluated in a follow-up period of 1 to 5 years. Of all five papers, associated surgery solely referred to anterior cruciate ligament reconstructions and to the treatment of meniscal tears whereas the exclusion criteria (see
Table 3) varied. In order to achieve comparability to the follow-up period of group B (2.9 years) we used the data evaluated by Gudas et al. and Knutsen et al. one or respectively two years postoperatively, resulting in an average follow-up period of 2.8 years. For outcome evaluation three numerical scores were applied, i.e., the Lysholm [38] and the IKDC Score [39] as well as the KOOS [40].

Whereas all patients of group A were treated by the microfracture technique as described by Steadman [15] the rehabilitation protocols of the five studies which are presented in Table 4 are not identical to his treatment regimen [30]. Nevertheless, they are similar, not allowing full weight-bearing for four to eight weeks postoperatively.

To be able to compare the two groups statistically we had to assign mean score values to group A at first. In consequence, we combined the results of Basad et al.'s and Knutsen et al.'s patients and we combined the results of Gudas et al.'s and Kon et al.'s patients, in order to calculate the mean Lysholm and the mean IKDC Score value, allocated to group A. Together with the four KOOS means they were compared to the average values of our patients (group B). Of interest, KOOS "sports" was excluded from the overall KOOS analysis by Saris et al., as their patients were significantly limited in sports activities so that hardly any data were available for this sub-domain.

Table 2 Demographic data of eligible studies (group A) and of own patients (group B).

\begin{tabular}{|c|c|c|c|c|c|c|c|c|c|c|c|c|c|c|}
\hline Study & $\begin{array}{l}\text { Study } \\
\text { design }\end{array}$ & Score & Patients & $\begin{array}{c}\text { Mean } \\
\text { age }\end{array}$ & $\begin{array}{l}\text { Ath- } \\
\text { letes }\end{array}$ & $\begin{array}{c}\text { Mean de- } \\
\text { fect size } \\
\left(\mathrm{mm}^{2}\right)\end{array}$ & $\begin{array}{c}\text { Fol- } \\
\text { low-up } \\
\text { time } \\
\text { (years) }\end{array}$ & \begin{tabular}{|c|} 
Final \\
Follow- \\
up \\
(years)
\end{tabular} & $\begin{array}{c}\text { Etio- } \\
\text { logy } \\
\text { trauma }\end{array}$ & $\begin{array}{l}\text { Etio- } \\
\text { logy } \\
\text { OCD }\end{array}$ & $\begin{array}{c}\text { Condy- } \\
\text { lar } \\
\text { defects }\end{array}$ & $\begin{array}{c}\text { Asso- } \\
\text { ciated } \\
\text { surgery }\end{array}$ & $\mid \begin{array}{c}\text { Previ- } \\
\text { ous } \\
\text { surgery }\end{array}$ & $\begin{array}{c}\text { Duration } \\
\text { of } \\
\text { symptoms } \\
\text { (months) }\end{array}$ \\
\hline $\begin{array}{l}\text { Basad et al. } \\
2010\end{array}$ & $\mathrm{RCT}$ & Lysholm & 17 & 37.5 & NR & $>400$ & 2 & 2 & $100 \%$ & $0 \%$ & $80 \%$ & $24 \%$ & NR & 30 \\
\hline $\begin{array}{l}\text { Gudas et al. } \\
2005\end{array}$ & RCT & IKDC & 29 & 24.3 & $100 \%$ & 277 & 1 & 3 & $56 \%$ & $44 \%$ & $100 \%$ & $0 \%$ & NR & 21 \\
\hline $\begin{array}{l}\text { Knutsen et } \\
\text { al. } 2007\end{array}$ & RCT & Lysholm & 40 & 31.1 & NR & 450 & 2 & 5 & $65 \%$ & $28 \%$ & $100 \%$ & $0 \%$ & $93 \%$ & 36 \\
\hline \begin{tabular}{|l} 
Konet al. \\
2009 \\
\end{tabular} & $\mathrm{COS}$ & IKDC & 40 & 30.6 & $96.5 \%$ & 250 & 5 & 5 & $68 \%$ & $0 \%$ & $95 \%$ & $70 \%$ & $25 \%$ & NR \\
\hline $\begin{array}{l}\text { Saris et al. } \\
2009\end{array}$ & RCT & KOOS & 61 & 33.9 & NR & 240 & 3 & 3 & $57 \%$ & $0 \%$ & $100 \%$ & $18 \%$ & $77 \%$ & 19 \\
\hline Group A & & & 187 & 32.4 & NR & $>244$ & 2.8 & 3.1 & $65 \%$ & $12.8 \%$ & $97 \%$ & $23 \%$ & NR & NR \\
\hline Group B & $\mathrm{CS}$ & & 26 & 39.7 & $35 \%$ & 216 & 2.9 & 2.9 & NR & $4 \%$ & $96 \%$ & $96 \%$ & $31 \%$ & NR \\
\hline
\end{tabular}



Those Presented in Controlled Studies?

Table 3 Exclusion criteria of the controlled studies.

\begin{tabular}{|c|c|c|c|c|}
\hline Basad et al. 2010 & Gudas et al. 2005 & Knutsen et al. 2007 & Kon et al. 2009 & Saris et al. 2009 \\
\hline Age $\leq 18, \geq 50$ years & Age $\geq 40$ years & Age $\leq 18, \geq 45$ years & Age $\leq 16, \geq 60$ years & Age $\leq 18, \geq 50$ years \\
\hline Lesion size $\leq 4, \geq 10 \mathrm{~cm}^{2}$ & Lesion size $\leq 1, \geq 4 \mathrm{~cm}^{2}$ & Lesion size $\leq 2, \geq 10 \mathrm{~cm}^{2}$ & Lesion size $\leq 1, \geq 5 \mathrm{~cm}^{2}$ & Lesion size $\leq 1, \geq 5 \mathrm{~cm}^{2}$ \\
\hline \multirow[t]{2}{*}{ Multiple chondral defects } & Multiple chondral defects & Multiple chondral defects & Kissing lesions & Multiple chondral defects \\
\hline & $\begin{array}{c}\text { ICRS } \\
\text { grade } 1 \text { and } 2\end{array}$ & $\begin{array}{l}\text { Outerbridge } \\
\text { grade } 1 \text { and } 2\end{array}$ & $\begin{array}{l}\text { Outerbridge } \\
\text { grade } 1 \text { and } 2\end{array}$ & $\begin{array}{l}\text { Outerbridge } \\
\text { grade } 1 \text { and } 2\end{array}$ \\
\hline \multicolumn{5}{|l|}{ Non-traumatic defects } \\
\hline $\begin{array}{c}\text { Trochlea or tibial plateau } \\
\text { lesions }\end{array}$ & $\begin{array}{c}\text { Patella, trochlea or tibial } \\
\text { plateau lesions }\end{array}$ & $\begin{array}{c}\text { Patella or tibial plateau } \\
\text { lesions }\end{array}$ & $\begin{array}{c}\text { Patella or tibial plateau } \\
\text { lesions }\end{array}$ & Patella or trochlea lesions \\
\hline $\begin{array}{c}\text { Instability of the knee } \\
\text { joint }\end{array}$ & \begin{tabular}{|c|} 
Patellofemoral instability, \\
ligament deficient knees
\end{tabular} & Patellofemoral instability & $\begin{array}{c}\text { Non-corrected knee } \\
\text { instability }\end{array}$ & $\begin{array}{l}\text { Complex ligamentous } \\
\text { instability }\end{array}$ \\
\hline $\begin{array}{l}\text { Planned or prior } \\
\text { menisectomy }\end{array}$ & & & & $\begin{array}{c}\text { Previous/present } \\
\text { meniscal transplant }\end{array}$ \\
\hline \multicolumn{5}{|l|}{ Inflammatory arthritis } \\
\hline & & & Pathologic changes & \\
\hline \multicolumn{5}{|l|}{ Osteonecrosis } \\
\hline \multirow[t]{3}{*}{ Chondrocalcinosis } & & Chondrocalcinosis & & \\
\hline & $\begin{array}{c}\text { Generalized } \\
\text { chondromalacia }\end{array}$ & & & \\
\hline & & & Osteochondritis dissecans & \\
\hline \multirow[t]{2}{*}{$\mathrm{BMI}>30 \mathrm{~kg} / \mathrm{m}^{2}$} & Overweight & $\mathrm{BMI}>30 \mathrm{~kg} / \mathrm{m}^{2}$ & & \\
\hline & $\begin{array}{c}\text { Occasionally or } \\
\text { non-sporting people }\end{array}$ & & & \\
\hline Osteoarthritis & Osteoarthritis & Osteoarthritis & Osteoarthritis & Osteoarthritis \\
\hline $\begin{array}{l}\text { Valgus or varus } \\
\text { abnormity }\end{array}$ & $\begin{array}{l}\text { Valgus or varus } \\
\text { abnormity }\end{array}$ & $\begin{array}{l}\text { Malalignment with more } \\
\text { than } 5^{\circ} \text { valgus or varus }\end{array}$ & $\begin{array}{l}\text { Valgus or varus } \\
\text { abnormity }\end{array}$ & $\begin{array}{l}\text { Malalignment with more } \\
\text { than } 5^{\circ} \text { valgus or varus }\end{array}$ \\
\hline
\end{tabular}

Table 4 Rehabilitation program.

\begin{tabular}{|c|c|c|c|c|c|}
\hline & Basad et al. 2010 & Gudas et al. 2005 & Knutsen et al. 2007 & Kon et al. 2009 & Saris et al. 2009 \\
\hline $\begin{array}{l}\text { Continous passive } \\
\text { motion }\end{array}$ & Yes & No & Yes & Yes & No \\
\hline $\begin{array}{l}\text { Postoperative brace } \\
\text { prescribed }\end{array}$ & $\begin{array}{l}\text { For patellar } \\
\text { lesions }\end{array}$ & No & No & No & $\begin{array}{l}\text { For the first } 8 \\
\text { weeks }\end{array}$ \\
\hline $\begin{array}{l}\text { No weight-bearing } \\
\text { permitted }\end{array}$ & & $\begin{array}{l}\text { For the first } 4 \\
\text { weeks }\end{array}$ & & $\begin{array}{l}\text { For the first } 2 \\
\text { weeks }\end{array}$ & $\begin{array}{l}\text { For the first } 2 \\
\text { weeks }\end{array}$ \\
\hline $\begin{array}{l}\text { Partial weight- } \\
\text { bearing permitted }\end{array}$ & $\begin{array}{l}\text { For the first } 6 \\
\text { weeks }\end{array}$ & $\begin{array}{l}\text { For the next } 4 \\
\text { weeks }\end{array}$ & $\begin{array}{l}\text { For the first } 8 \\
\text { weeks }\end{array}$ & $\begin{array}{l}\text { For the next } 1 \text { or } 2 \\
\text { weeks }\end{array}$ & $\begin{array}{l}\text { For the next } 4 \\
\text { weeks }\end{array}$ \\
\hline $\begin{array}{l}\text { Weight-bearing per- } \\
\text { mitted as tolerated }\end{array}$ & After 6 weeks & & & After 3 or 4 weeks & After 6 weeks \\
\hline $\begin{array}{l}\text { Full weight-bearing } \\
\text { permitted }\end{array}$ & & After 8 weeks & After 8 weeks & & \\
\hline
\end{tabular}

For the data presented in Table 5 a correlation analysis was performed by SPSS-18. Of the Pearson coefficient, a value of $0.924(\mathrm{p}=0.008)$ was calculated which indicated a very high positive linear correlation [41] between the score values of group A and B. This result was graphically displayed in Fig. 1.

For every score a number pair was charted in a scatter plot, assigning the relevant score value of group A (variable on the $\mathrm{x}$-axis) to every score value of group B (variable on the y-axis). Fig. 1 reveals that the two variables yield a relatively straight line. Of course, the results evaluated by Basad et al., Gudas et al., Knutsen et al., Kon et al. and Saris et al. do not cause our results and vice versa; the mean score values of group A and group B are independently related to a third variable that influences both - the 

Those Presented in Controlled Studies?

outcome. Due to the fact that higher score values represent higher levels of function and lower levels of symptoms, score values and outcome correlate positively. Therefore, the very high correlation between the score values of group A and group B can only by explained by a similar outcome that has been achieved by microfracture of the knee in both patient populations.

Table 5 Mean score values.

\begin{tabular}{|l|c|c|c|c|c|c|c|}
\hline & $\begin{array}{c}\text { Basad et al. } \\
2010\end{array}$ & $\begin{array}{c}\text { Gudas et al. } \\
2005\end{array}$ & $\begin{array}{c}\text { Knutsen et } \\
\text { al. 2007 }\end{array}$ & $\begin{array}{c}\text { Kon et al. } \\
2009\end{array}$ & $\begin{array}{c}\text { Saris et al. } \\
2009\end{array}$ & Group A & Group B \\
\hline Lysholm Score & 69 & & 75 & & & 73.2 & 80.5 \\
\hline IKDC Score & & 76 & & 70.2 & & 72.5 & 70.6 \\
\hline KOOS "function in daily living" & & & & & 87.26 & 87.26 & 83.15 \\
\hline KOOS "pain" & & & & & 81.20 & 81.20 & 78.31 \\
\hline KOOS "symptoms/stiffness" & & & & & 79.81 & 79.81 & 77.96 \\
\hline KOOS "quality of life" & & & & & 52.45 & 52.45 & 60.96 \\
\hline
\end{tabular}

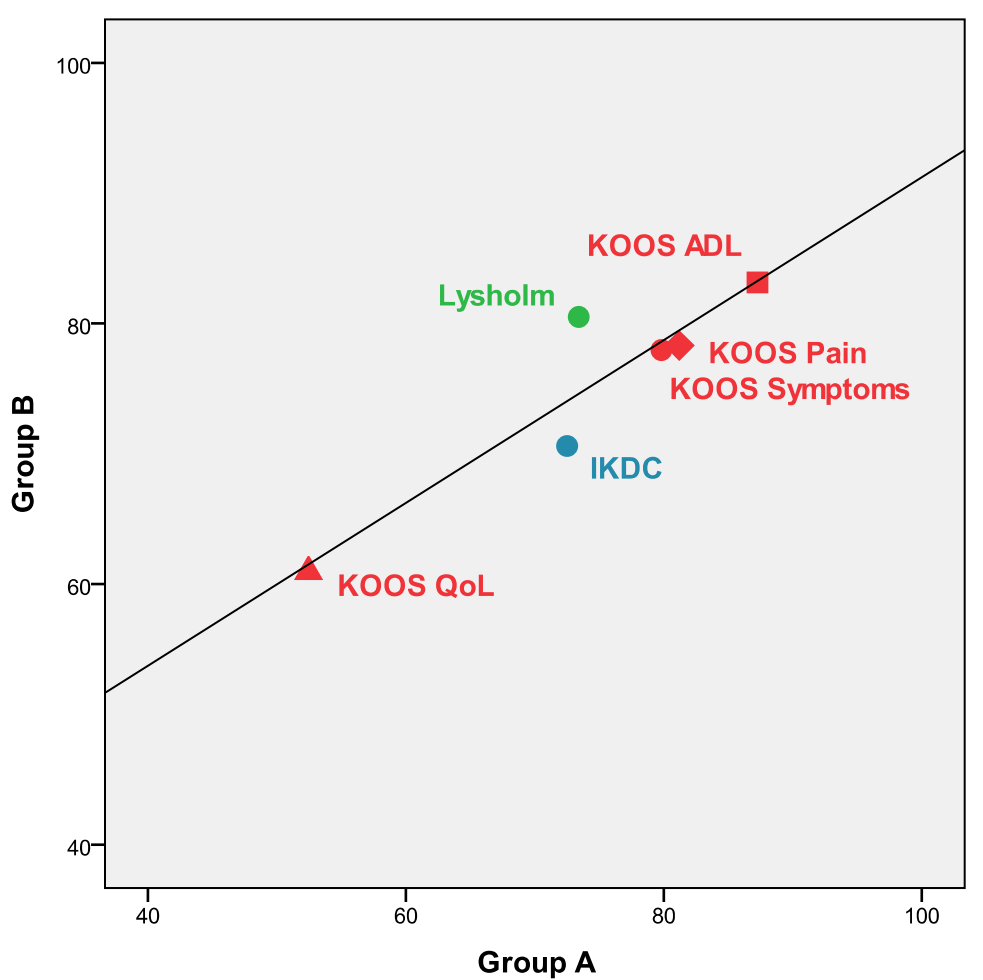

Fig. 1 Scatter plot of data points according to the respective clinical score.

\section{Discussion}

According to evidence-based medicine randomized controlled trials (RCT) provide the gold standard for determining the effectiveness of medical interventions [42]. As selection, performance, detection and attrition biases are minimized by randomization the strength of RCTs lies in their internal validity [43]. Due to the fact that treatment groups only differ in the intervention provided to them, differences in observed effects can be attributed to differences in the intervention, resulting in adequate treatment guidelines for clinical practice. Nevertheless, strict exclusion criteria may lead to a population being assessed that is very different to that treated on a daily basis. As a consequence, the question of the external 

Those Presented in Controlled Studies?

validity of a RCT inevitably arises when its evidence has to be applied to an individual patient [44, 45]. However, the more similar a patient is to those recruited to the trial the more similar results can be expected by applying this treatment to him/her. But in general, the results of randomized controlled trials which refer to the treatment of cartilage defects may not be representative for the general population [46]. Therefore, due to our inhomogeneous patient population we expected results worse than those of the five controlled studies detected by our literature search. Although our correlation analysis revealed statistically comparable results, we must not generalize our findings. They only suggest that outcome achieved by microfracture can, but does not need to be, similar for a homogenous patient population which is presented in controlled studies and for patients in clinical practice to whom no strict predetermined inclusion criteria had been applied. In consequence, controlled studies may reflect general population results and therefore provide estimates of treatment effects which are applicable in daily clinical practice. In consequence, a rough assessment of the expected improvement achieved by microfracture is possible preventing patients from unrealistic expectations.

Limitations of our study include the fact that the number of our patients was very small and that only five number pairs were available for calculating the Pearson correlation coefficient. Nevertheless, we performed the One-Sample Kolmogorov-Smirnov Test which only revealed normal distribution for variable $x(p=0.975)$. For group $B, p=0.802$ was computed.

\section{Acknowledgement}

We would like to thank $H$. Schlumprecht for reviewing the statistics.

\section{References}

[1] F. T. Blevins, J. R. Steadman, J. J. Rodrigo and J. Silliman, Treatment of articular cartilage defects in athletes: An analysis of functional outcome and lesion appearance, Orthopedics 21 (1998) 761-768.

[2] J. R. Steadman, B. S. Miller, S. G. Karas, T. F. Schlegel, K. K. Briggs and R. J. Hawkins, The microfracture technique in the treatment of full-thickness chondral lesions of the knee in National Football League players, J Knee Surg 16 (2003) 83-86.

[3] Steadman J. R., Briggs K. K., Rodrigo J. J., Kocher M. S., Gill T. J. and Rodkey W. G., Outcomes of microfracture for traumatic chondral defects of the knee: Average 11-year follow-up, Arthroscopy 19 (2003) 477-484.

[4] Bae D. K., Yoon K. H. and Song S. J., Cartilage healing after microfracture in osteoarthritic knees, Arthroscopy 22 (2006) 367-374.

[5] Miller B. S., Steadman J. R., Briggs K. K., Rodrigo J. J. and Rodkey W. G., Patient satisfaction and outcome after microfracture of the degenerative knee, J Knee Surg 17 (2004) 13-17.

[6] Akgun I., Kesmezacar H., Ogut T. and Kanberoglu K., Arthroscopic microfracture treatment for osteonecrosis of the knee, Arthroscopy 21 (2005) 834-843.

[7] K. Mithoefer, T. McAdams, R. J. Williams, P. C. Kreuz and B. R. Mandelbaum, Clinical efficacy of the microfracture technique for articular cartilage repair in the knee: An evidence-based systematic analysis, Am J Sports Med 37 (2009) 2053-2063.

[8] Safran M. R. and K. Seiber, The evidence for surgical repair of articular cartilage in the knee, J Am Acad Orthop Surg 18 (2010) 259-266.

[9] Williams J. R. and H. W. Harnly, Microfracture: indications, technique, and results, AAOS Instructional Course Lectures 56 (2007) 419-428.

[10] T. J. Gill, P. D. Asnis and E. M. Berkson, The treatment of articular cartilage defects using the microfracture technique, J Orthop Sports Phys Ther 36 (2006) 728-738.

[11] Bekkers J. E. J., M. Inklaar and D. B. F. Saris, Treatment selection in articular cartilage lesions of the knee: A systematic review, Am J Sports Med 37 (2009) 148S-155S.

[12] E. J. Strauss, J. U. Barker, J. S. Kercher, B. J. Cole and K. Mithoefer, Augmentation strategies following the microfracture technique for repair of focal chondral defects, Cartilage 1 (2010) 145-152.

[13] Mithoefer K., Williams R. J., Warren R. F., Potter H., Spock C. and Jones E. et al., The microfracture technique for the treatment of articular cartilage lesions in the knee. A prospective cohort study, J Bone Joint Surg Am 87 (2005) 1911-1920.

[14] G. Knutsen, L. Engebretsen, T. C. Ludvigsen, J. O. Drogset et al., Autologous chondrocyte implantation 


\section{Microfracture of the Knee: Are The Results Achieved In Clinical Practice Statistically Comparable to Those Presented in Controlled Studies?}

compared with microfracture in the knee: A randomized trial, J Bone Joint Surg Am 86A (2004) 455-464.

[15] J. R. Steadman, W. G. Rodkey, S. B. Singleton and K. K. Briggs, Microfracture technique for full thickness chondral defects: Technique and clinical results, Operat Tech Orthop 7 (1997) 300-304.

[16] A. Gobbi, P. Nunag and K. Malinowski, Treatment of chondral lesions of the knee with microfracture in a group of athletes, Knee Surg Sports Traumatol Arthrosc 13 (2005) 213-221.

[17] D. D. Frisbie, G. W. Trotter, B. E. Powers, J. R. Steadman, R. D. Howard, R. D. Park and Mcllwraith C. W., Arthroscopic subchondral bone plate microfracture technique augments healing of large osteochondral defects in the radial carpal bone and medial femoral condyle of horses, J Vet Surg 28 (1999) 242-255.

[18] D. D. Frisbie, J. T. Oxford, L. Southwood, G. W. Trotter, W. G. Rodkey, J. R. Steadman, J. L. Goodnight and C. W. McIlwraith, Early events in cartilage repair after subchondral bone microfracture, Clin Orthop Relat Res 407 (2003) 215-227.

[19] G. Knutsen, J. O. Drogset, L. Engebretsen, T. Grontvedt, V. Isaksen, T. C. Ludvigson, S. Roberts, E. Solheim, T. Strand and O. Johansen, A randomized trial comparing autologous chondrocyte implantation with microfracture. Findings at five years, J Bone Joint Surg Am 89 (2007) 2105-2112.

[20] G. Knutsen, L. Engebretsen, T. C. Ludvigsen, J. O. Drogset, T. Grontvedt, E. Solheim, T. Strand, S. Roberts, V. Isaksen and O. Johansen, Autologous chondrocyte implantation compared with microfracture in the knee. A randomized trial, J Bone Joint Surg Am 86A (2004) 455-464.

[21] P. C. Kreuz, C. Erggelet, M. R. Steinwachs, S. J. Krause, A. Lahm, P. Niemeyer, N. Ghanem, M. Uhl and N. Südkamp, Is microfracture of chondral defects in the knee associated with different results in patients aged 40 years or younger? Arthroscopy 22 (2006) 1180-1186.

[22] P. C. Kreuz, M. R. Steinwachs, C. Erggelet, S. J. Krause, G. Konrad, M. Uhl and N. Südkamp, Results after microfracture of full-thickness chondral defects in different compartments in the knee, Osteoarthritis Cartilage 14 (2006) 1119-1125.

[23] K. Mithoefer, R. J. Williams, R. F. Warren, H. Potter, C. Spock, E. Jones, T. L. Wickiewicz and R. G. Marx, The microfracture technique for the treatment of articular cartilage lesions in the knee. A prospective cohort study, J Bone Joint Surg Am 87 (2005) 1911-1920.

[24] K. Mithoefer, R. J. Williams, R. F. Warren, T. L. Wickiewicz and R. G. Marx, High-impact athletics after knee articular cartilage repair: A prospective evaluation of the microfracture technique, Am J Sports Med 34 (2006) 1413-1419.

[25] N. A. Sgaglione, W. Del Pizzo, J. M. Fox and M. J. Friedman, Critical analysis of knee ligament rating systems, Am J Sports Med 23 (1995) 660-667.

[26] K. Labs and B. Paul, To compare and contrast the vartious evaluating scoring systems after anterior cruciate ligament reconstruction, Arch Orthop Trauma Surg 116 (1997) 92-96.

[27] S. Bollen and B. B. Seedhom, A comparison of the Lysholm and Cincinnati knee scoring questionnaires, Am J Sports Med 19 (1991) 189-190.

[28] G. Peters, C. J. Wirth and D. Kohn, Vergleich von Scores und Bewertungsschemata bei Knieinstabilitäten, Z Orthop 135 (1997) 63-69.

[29] S. Fuchs and M. Friedrich, Der Einfluß des Patientenalters auf die Anwendung von Kniegelenkscores, Z Orthop Ihre Grenzgeb 137 (1999) 322-329.

[30] J. R. Steadman, W. G. Rodkey and J. J. Rodrigo, Microfracture: surgical technique and rehabilitation to treat chondral defects, Clin Orthop Relat Res 391 (Suppl) (2001) 362-369.

[31] R. A. Marder, G. Hopkins and L. A. Timmerman, Arthroscopic microfracture of chondral defects of the knee: A comparison of two postoperative treatments, Arthroscopy 21 (2005) 152-158.

[32] E. Basad, B. Ishaque and G. Bachmann, Matrix-induced autologous chondrocyte implantaion versus microfracture in the treatment of cartilage defects of the knee: A 2-year randomized study, Knee Surg Sports Traumatol Arthrosc 18 (2010) 519-527.

[33] R. Gudas, R. J. Kalesinskas, V. Kimtys, E. Stankevicius, V. Toliusis, G. Bernotavicius and A. Smailys, A prospective randomized clinical study of mosaic osteochondral autologous transplantation versus microfracture for the treatment of osteochondral defects in the knee joint in young athletes, Arthroscopy 21 (2005) 1066-1075.

[34] R. Gudas, E. Stankevicius, E. Monastyreckiene, D. Pranys, R. J. Kalesinskas, Osteochondral autologous transplantation versus microfracture for the treatment of articular cartilage defects in the knee joint in athletes, Knee Surg Sports Traumatol Arthrosc 14 (2006) 834-842.

[35] D. B. F. Saris, J. Vanlauwe, J. Victor, M. Haspl, M. Bohnsack, Y. Fortems, B. Vandekerckhove, K. F. Almqvist, T. Claes, F. Handelberg, K. Lagae, J. van der Bauwhede, H. Vandenneucker, K. G. Yang, M. Jelic, R. Verdonk, N. Veulemans, J. Bellemans, F. P. Luyten, Characterized chondrozyte implantation results in better structural repair when treating symptomatic cartilage 


\section{Those Presented in Controlled Studies?}

defects of the knee in a randomized controlled trial versus microfracture, Am J Sports Med 36 (2008) 235-246.

[36] D. B. F. Saris, J. V. Vanlauwe, J. V. Almquist, R. Verdonk, J. Bellemans, F. P. Luyten, Treatment of symptomatic cartilage defects of the knee: Characterized chondrocyte implantation results in better clinical outcome at 36 months in a randomized trial compared to microfracture, Am J Sports Med 37 (2009) 10S-19S.

[37] E. Kon, A. Gobbi, G. Filardo, M. Delcogliano, S. Zaffagnini and M. Marcacci, Arthroscopic second-generation autologous chondrocyte implantation compared with microfracture for chondral lesions of the knee, Am J Sports Med 37 (2009) 33-41.

[38] Lysholm J. and Gillquist J., Evaluation of knee ligament surgery results with special emphasis on use of a scoring scale, Am J Sports Med 10 (1982) 150-154.

[39] ICRS, available online at: http://www.cartilage.org.

[40] E. M. Roos, P. H. Roos, L. S. Lohmander, C. Eckdahl, B. D. Beynonn, Knee Injury and Osteoarthritis Outcome Score (KOOS): Development of a self-administrated outcome measure, J Orthop Sports Phys Ther 28 (1998) $88-96$.
[41] C. Tredoux and K. Durheim, Numbers, hypothesis \& conclusions: a course in statistics for the social sciences, Landsdowne: UCT Press, 2007.

[42] D. L. Sackett, W. M. C. Rosenberg, J. A. M. Gray, R. B. Haynes and W. S. Richardson, Evidence-based medicine: What it is and what it isn't, BMJ 312 (1998) 71-71.

[43] K. Dalziel, A. Round, K. Stein, R. Garside, E. Castelnuovo and L. Payne, Do the findings of case series studies vary significantly according to methodological characteristics? Health Technol Assess (2005) 9.

[44] T. Fahey, Applying the results of clinical trials to patients to general practice: Perceived problems, strengths, assumptions, and challenges for the future, $\mathrm{Br} \mathrm{J}$ Gen Pract 48 (1998) 1173-1178.

[45] P. M. Rothwell, External validity of randomized controlled trials: "To whom do the results of this trial apply?", Lancet 365 (2005) 82-93.

[46] C. E. Engen, L. Engebretsen and A. Aroen, Knee cartilage defect patients enrolled in randomized controlled trials are not representative of patients in orthopedic practice, Cartilage 1 (2010) 312-319. 